\title{
TECTONIC PROCESSES AND CRUSTAL EVOLUTION ON/OFFSHORE WESTERN PELOPONNESE DERIVED FROM ACTIVE AND PASSIVE SEISMICS
}

\author{
Papoulia J. ${ }^{1}$ and Makris J. ${ }^{2}$ \\ ${ }^{1}$ Hellenic Centre for Marine Research, Institute of Oceanography, 19013 Anavissos, Attiki, \\ Greece,nana@ath.hcmr.gr \\ ${ }^{2}$ GeoPro GmbH, 20457 Hamburg, Germany, info@geopro.com
}

\begin{abstract}
We developed velocity models of the crust and sediments offshore south western Greece, between the island of Zakynthos and Messinia. Using these velocity models and depth migrating the seismic data we delineated the main faults and associated them with the tectonic processes of western Greece. This active seismic experiment was essential for defining the limits between the continental domain of western Greece and the oceanic one of the deep Ionian Sea.

We successfully linked the onshore with the offshore tectonics and for the first time it was possible to understand how the main dextral fault systems of Cephalonia and Andravida are responsible for the crustal deformation, and its link to the local seismicity. Most of the seismic activity is connected to thrusting, due to crustal shortening or strike-slip faulting that follows the two main dextral wrench faults of Cephalonia and Andravida. It was recognized that the back stop offshore western Peloponnese is floored by thinned continental crust of Preapulia and that the Hellenic Alpine napes do not extend in the back stop domain.
\end{abstract}

Key words: crustal structure, Ionian Sea, Hellenides, Mediterranean Ridge.

\section{Introduction}

Aim of this study was to map the structure of sediments and crust between Zakynthos and Messinia, southwestern Peloponnese. Particularly the Kiparissiakos gulf and the transition of the continental to the oceanic domains were of special interest. Existing multi channel reflection seismic data, due to the length of the streamer systems used, had never before successfully penetrated at crustal depths, and the crustal thickness had never been uniquely defined (Kamberis et al., 1996; Kokinou et al., 2005). Furthermore, it was our intention to map the main tectonic elements along the crustal models. By connecting the offshore with the onshore tectonic elements we wanted to follow the continuation of the Alpine napes in the offshore. We also intended to locate the continent ocean transition in the offshore and better understand the tectonisation of the backstop and its interaction with the Mediterranean Ridge.

To accomplish this task, we used 60 Ocean Bottom Seismographs (OBSs) and deployed them successively along 5 seismic profiles south of the island of Zakynthos (Fig. 1). In the following we will present the crustal results of this experimental effort and a tectonic map of the Kiparissiakos gulf and the backstop to the west. 


\section{Geological setting}

The area of study is located along the western Peloponnese continental Margin, between the island of Zakynthos to the north and the coast of Messinia peninsula to the south. This segment of the western Hellenic margin is seismically very active (Makropoulos and Burton, 1981; Papazachos and Papazachou, 1997) deforming rapidly with many destructive earthquakes, landslides and a tremendous bathymetric depression of approximately $5000 \mathrm{~m}$ in the Matapan basin. Isostasy is also disturbed, and as Makris (1977) showed, at the Peloponnese-Ionian Sea transition the isostatic balance is under compensated.

Onshore western Peloponnese the outcrops of the Gavrovo, Ionian and Preapulia have been mapped by Auboin and Decourt (1962). The Ionian zone is outcropping in the southeastern part of Zakynthos island as intruded Triassic evaporites into Plio-Pleistocene deposits (Underhill, 1989), while preApulian limestones constitute most of the western half of the island. On Strophades island outcrops of salty evaporites have been described as tectonically emplaced diapirs into Pliocene marls, and hypothetically attributed to Messinian deposits (Lyberis and Bizon, 1981). Finally along the Peloponnese coasts of Kyparissiakos gulf outcrops of the Ionian, Gavrovo and Pindos alpine units are known together with continental, marine Pleistocene to Holocene deposits, truncated by E-W trending extensional active faults (Papanikolaou et al., 2007). Offshore only little information is available mainly from seismological and seismic studies. Clement et al., (2000) have investigated the seismic structure of the intra-plate geometry between Cephalonia and Zakynthos. Monopolis and Bruneton (1982) and, more recently, Papanikolaou et al., (2007) have studied the shallow geological structure of this continental margin segment. Aubouin et al., (1976) and Le Pichon et al., (2002) have proposed continuity of the alpine units, and particularly of the Ionian thrusts, beneath most of the area. Papanikolaou et al., (2007) have discussed the various rate of subsidence on the shelf area during Pleistocene to Holocene times and tentatively evidenced a "so-called" coastal fault zone along the Kiparissiakos gulf which they relate to a major change in paleo-geography during Pleistocene times.

\section{The seismic experiment}

We used 20 to 40 Ocean Bottom Seismographs (OBSs) and observed five 2D profiles in the Kiparissiakos gulf, southwestern Peloponnese, Greece (see Fig. 1).

Inline spacing of the OBSs was 3 to $5 \mathrm{~km}$. Seismic energy was generated by shots fired every $125 \mathrm{~m}$ from a tuned air gun array of 2960 cuin. Dominant frequency of the shots was $8 \mathrm{~Hz}$. Data were evaluated by: first break tomography, layered tomography, two point ray tracing forward modeling and depth migration of reflected and refracted arrivals.

\section{Profile P1_2006}

This NNW-SSE oriented profile produced important information on the E-W oriented fault systems. It mapped the offshore continuation of several onshore faults of western Peloponnese. For the correlation with the tectonic elements onshore we used three sources: the Seismotectonic map of IGME (1989), Mariolakos et al. (1998) and Papanikolaou et al., (2007). The final velocity model with a tectonic interpretation is presented in Figure 2. The Kiparissiakos basin is separated by a series of faults in three sub basins, which are deforming by extension. The crust below the Basin is relatively thin, approximately $22 \mathrm{~km}$. Between OBS 0 and 1, east of Zakynthos, a major fault was identified separating a thicker continental block to the north from a thinner one to the south. This major fault at the northwestern flank of the Kiparissiakos basin is seismically active and may extend onshore, in the area of Killini. To the south the Basin is terminated by another major normal fault located approxi- 


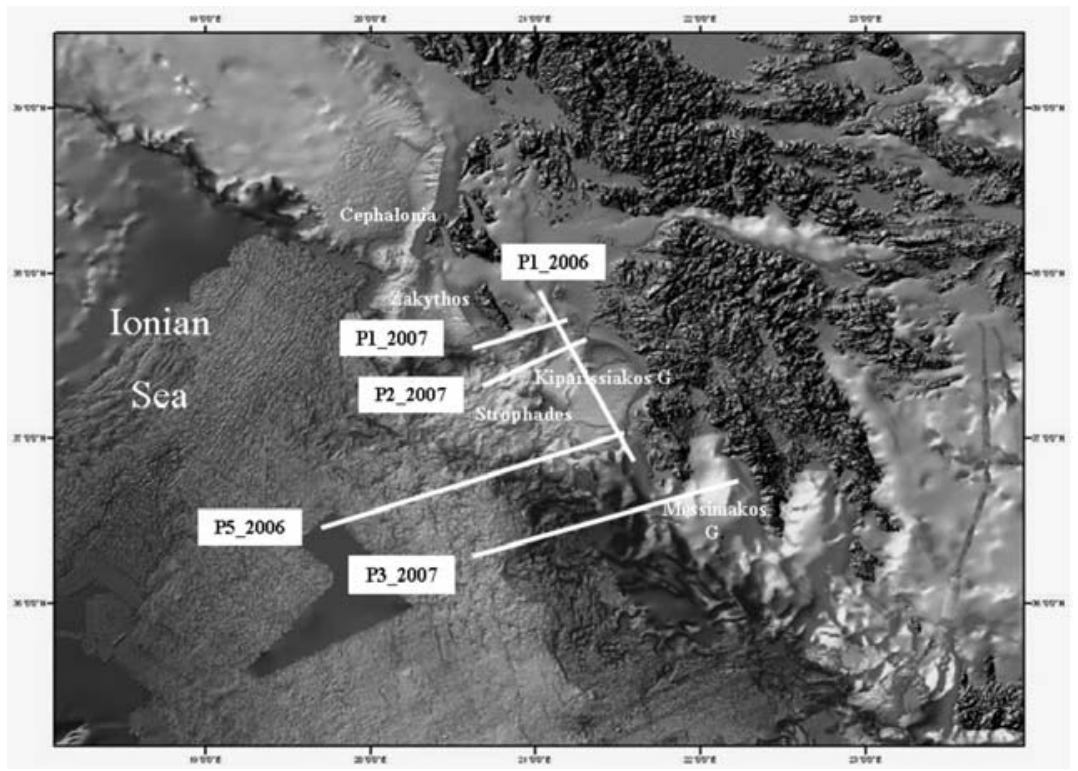

Fig. 1: Location of the five OBS seismic profiles offshore south western Peloponnese.

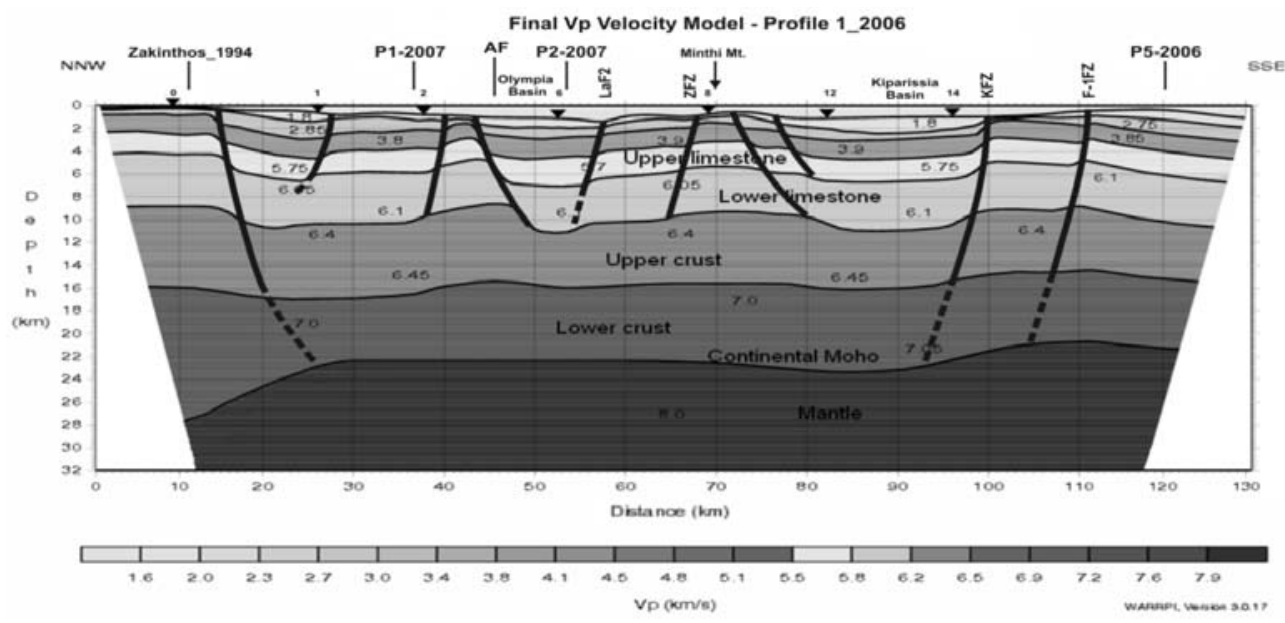

Fig. 2: Velocity Model of profile P1_2006 with tectonic interpretation.

mately $5 \mathrm{~km}$ south of OBS 14 and it is the westwards continuation of the Kiparissiakos Fault Zone (KFZ) (see Fig. 3). South of this fault the sedimentary sequences are dipping southwards and the crust is thinned to approximately $21 \mathrm{~km} .15 \mathrm{~km}$ south of OBS 14 we identified a normal fault dipping northwards, which is the offshore continuation of the onshore mapped fault F-1FZ, north of Filiatra (Mariolakos et al., 1998).

In the central part of the Profile, close to OBS 8, we have mapped an anticline with uplifted sediments deforming also the bathymetry. This anticline is the offshore extension of the Minthi mountain. The normal faults defining the flanks of this anticline correlate with those mapped onshore. 


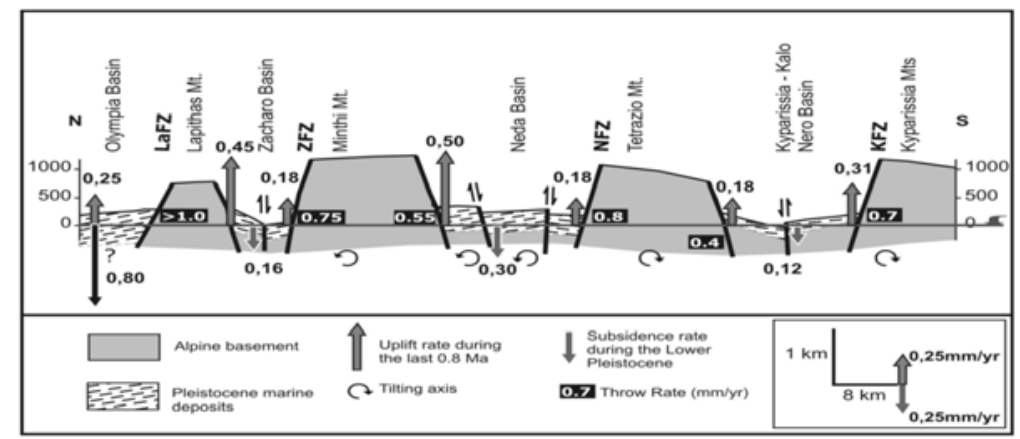

Fig. 3: Schematic cross section from Olympia basin to Kyparissia mountains, western Peloponnese (from Papanikolaou et al., 2007)
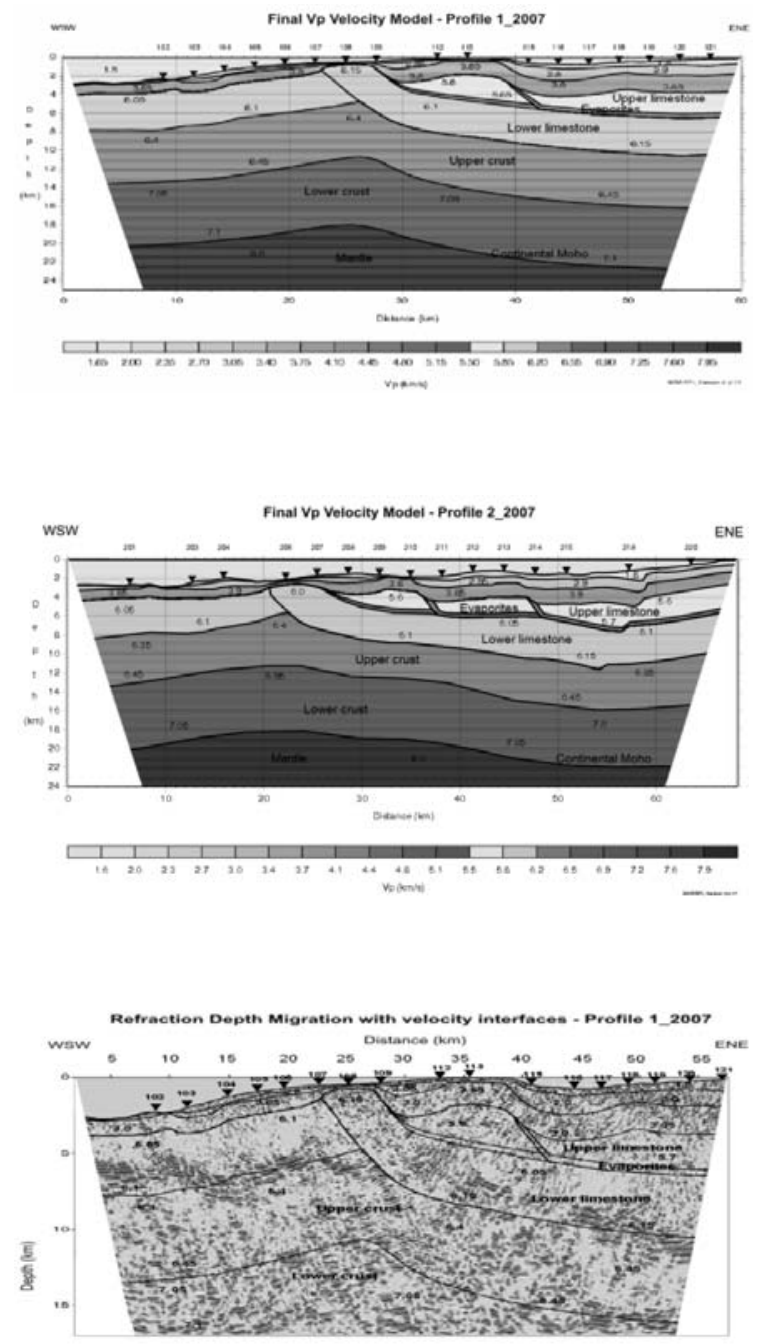

Fig. 4: Velocity Model of profile P1_2007.

Fig. 5: Velocity Model of profile P2_2007.

Fig. 6: Depth Migrated seismic data of profile 1_2007 superimposed with velocity interfaces. 


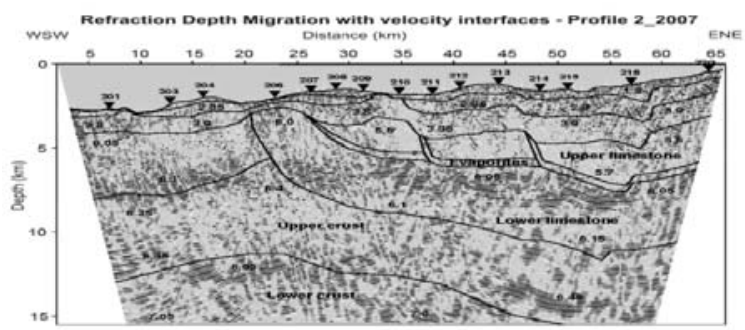

Fig. 7: Depth Migrated seismic data of profile P2_2007 superimposed with velocity interfaces (b).

North of OBS 8 we mapped the offshore continuation of the Lapithas Fault Zone (LaFZ). This fault is the southern flank of the Olympia basin. To the north the Basin is flanked by a normal fault dipping southwards. The continuation of this fault offshore creates a rhombic shape basin, mapped by swath bathymetry (Wardel and Mascle, personal communication, SEAHELLARC technical reports). Significant seismic activity was mapped in this Basin at crustal and sub-crustal levels (Papoulia et al., 2009). Seismicity and focal mechanisms indicate that it has developed by transtensional dextral wrench faulting. We consider this system to be the offshore extension of the Andravida dextral strike slip fault.

\section{Profiles P1_2007 \& P2_2007}

Both E-W profiles south of Zakynthos have mapped a major thrust, which is the western limit of the Ionian zone of the Hellenic Alpine units to the Preapulia (Figs 4 and 5). Profile 2_2007 shows a significant shift of the Ionian zone and Preapulia thrust to the west; this is due to the influence of the dextral motion along the Andravida strike slip fault. The velocities of $5.6 \mathrm{~km} / \mathrm{s}$ and $6.1 \mathrm{~km} / \mathrm{s}$ are assigned to two different metamorphic limestones, an upper and a lower one, which, as we have also seen in previously observed seismic data from the Zakynthos island (Makris and Papoulia, 2009), are separated by evaporites of Triassic age (Nikolaou, personal communication).

In Figures 6 and 7 we present the depth migrated OBS data using the refraction migration technique (Pilipenko and Makris, 1997). The basement geometry is very clearly mapped and it shows the thrusting at the central part of the line and also the tectonized and shortened crustal geometry to the west of the thrusting front. The superimposed interfaces of the velocity model show a good coincidence between the migrated interfaces and those computed by ray tracing. The ray traced structures however are significantly smoothed. The tectonic details and crustal deformation can only be resolved by a reliably applied migration procedure.

\section{Profile P5_2006}

Low velocity sediments of Vp values ranging between $2.2 \mathrm{~km} / \mathrm{s}$ and $3.7 \mathrm{~km} / \mathrm{s}$ thicken systematically from OBS position 4 to OBS position 19, that is from west to east (Fig. 8). This indicates a gradual subsidence of the oceanic crust towards the collision front, at the Mediterranean Ridge. The western limit of the continental backstop over thrusts the sediments of the Mediterranean Ridge. The subduction of the oceanic slab at this limit is very clearly mapped, following the geometry of the continental Moho. The continental crust thickness at the backstop area to approximately $16 \mathrm{~km}$ and was mapped at a depth of $20 \mathrm{~km}$. The oceanic slab below the continental crust was not directly mapped and was assumed as a continuation of the identified oceanic crust below the deep Ionian Sea. We could not resolve any sediments to be involved with the subduction.

The continental part of the profile is covered with thick sediments. We have again identified the exis- 


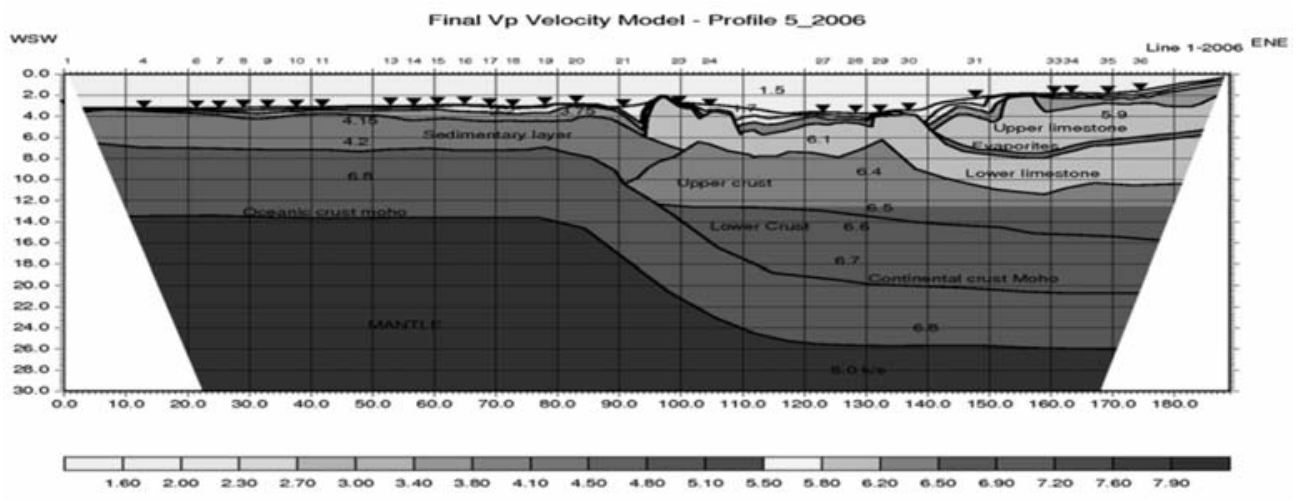

Fig. 8: Velocity Model of profile P5_2006.

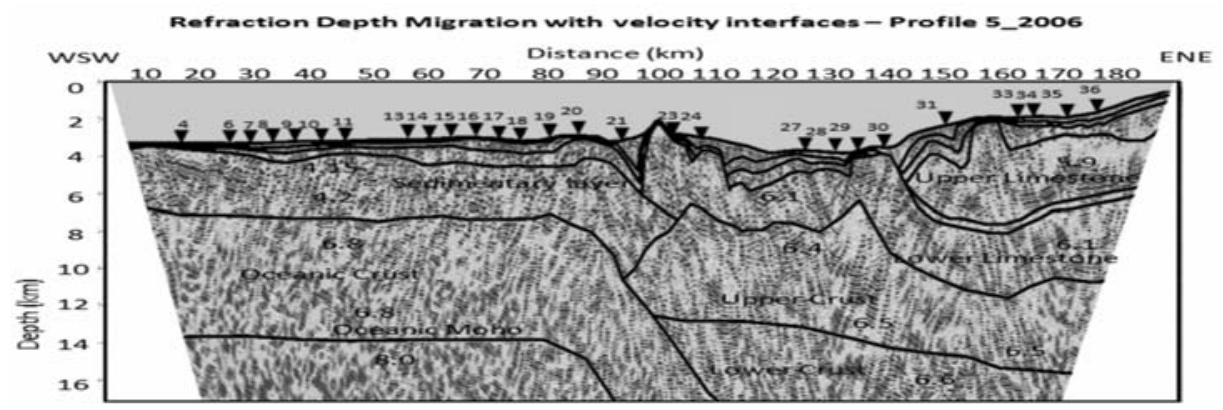

Fig. 9: Depth migrated seismic data of profile 5_2006 superimposed with velocity interfaces.

tence of two high velocity limestone series separated by Triassic evaporites. The upper limestone is terminated at OBS 30, where the uplifted and thrusted lower limestone of Preapulia is nearly exposed to the sea floor. This part of the section coincides with the deepest part of the bathymetry of about $4000 \mathrm{~m}$ water depth, and is part of the Hellenic Trench. The backstop area is covered by soft sediments with increasing thickness to the west, deposited on the Preapulia limestone, and is strongly tectonized. The upper limestones representing the Hellenic napes are terminated at the Preapulia thrust (OBS 30).

The migrated section, presented in Figure 9, is limited to the upper $14 \mathrm{~km}$ and is overlapped by the velocity interfaces defined by the velocity model of Figure 8 . The strongly tectonized upper crustal units are also seen in the migration section. The structural elements mapped by both the velocity modeling and the refraction migration is in good agreement. It is obvious that the eastern part of the profile, to the east of the collision front, is very strongly tectonized by three major thrusts and several normal faults. On the contrary the deep Ionian basin is fairly homogeneous and strong deformation is only observed at the Mediterranean Ridge.

\section{Profile P3_2007}

At the western part of the profile, between OBS 341 and OBS 328, we have mapped two high velocity limestone series again separated by the Triassic evaporites, as was identified in all previous lines (Fig. 10). Two main thrusts were mapped in this area. The western one at OBS 335 is within the Hellenic Alpine units and was correlated with the onshore structures of Messinia, specifically lim- 


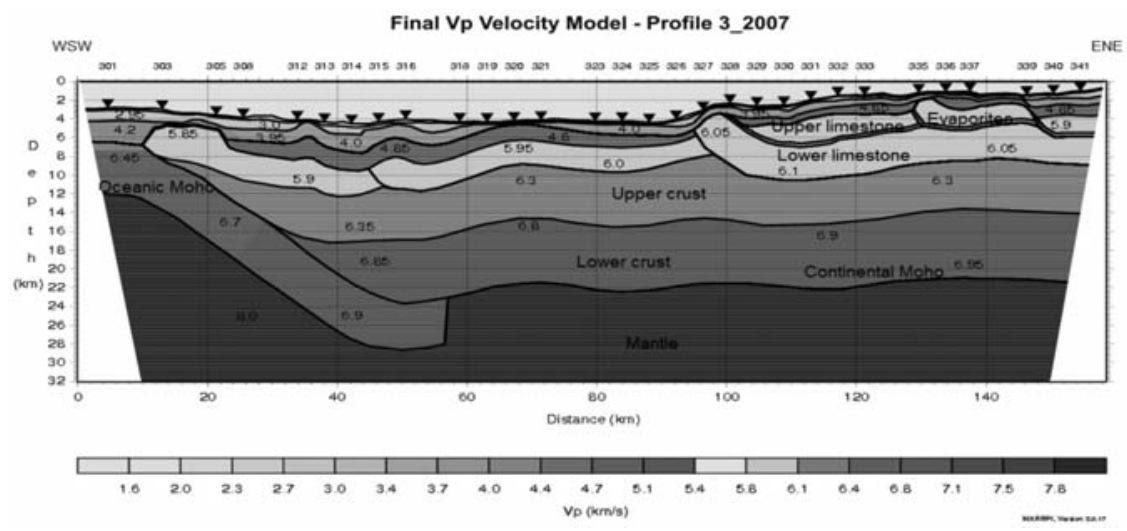

Fig. 10: Velocity Model of profile P3_2007.

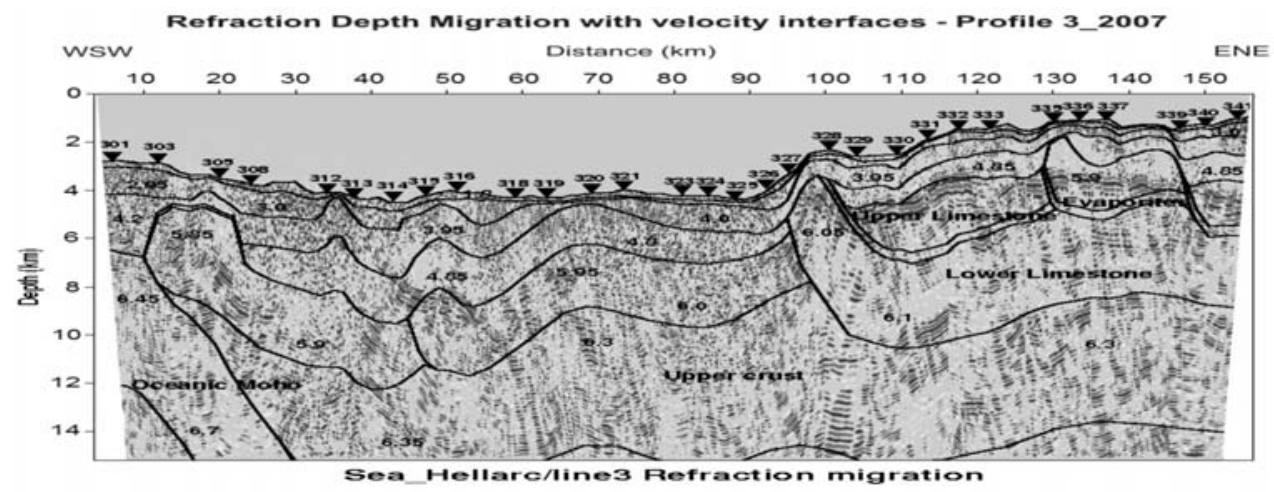

Fig. 11: Depth migrated seismic data of profile 3_2007 superimposed with velocity interfaces

iting the Gavrovo zone to the east from the Ionian zone to the west. The second major thrust is located at OBS 328. The lower limestone of Preapulia is nearly exposed to the surface and defines the western limit of extension of the Hellenic napes. From this thrust front until OBS 303, which is nearly at the western end of the profile, only one high velocity limestone has been identified. All this area is considered to be the continental backstop. The Mediterranean Ridge is clearly marked to the west of this location by a bathymetric uplift and change of the sedimentary structure. The transition zone between the Mediterranean Ridge and the Preapulia backstop is deformed by intense fragmentation of the stretched continental crust of Preapulia and by thrusting of the high velocity limestones over the soft sediments of the Mediterranean Ridge. The sediments at the backstop area thicken from east to west. The thickest part of the post Preapulia sediments is identified below OBS 314 and is about $5 \mathrm{~km}$. Vp velocity of the sediments ranges between $4.0 \mathrm{~km} / \mathrm{s}$ and $4.85 \mathrm{~km} / \mathrm{s}$. We did not follow the oceanic slab below the backstop because energy failed to penetrate below the continental Moho. The later was encountered at a depth of approximately $22 \mathrm{~km}$.

We have again plotted the velocity discontinuities produced by the ray tracing modeling into the depth migrated OBS arrivals of Figure 11. We present only the upper $15 \mathrm{~km}$ part of the section in order to obtain a better resolution of the tectonic elements. Two main zones of significant thrusting and crustal shortening were mapped. The eastern one, between OBS 327 and OBS 341, includes 


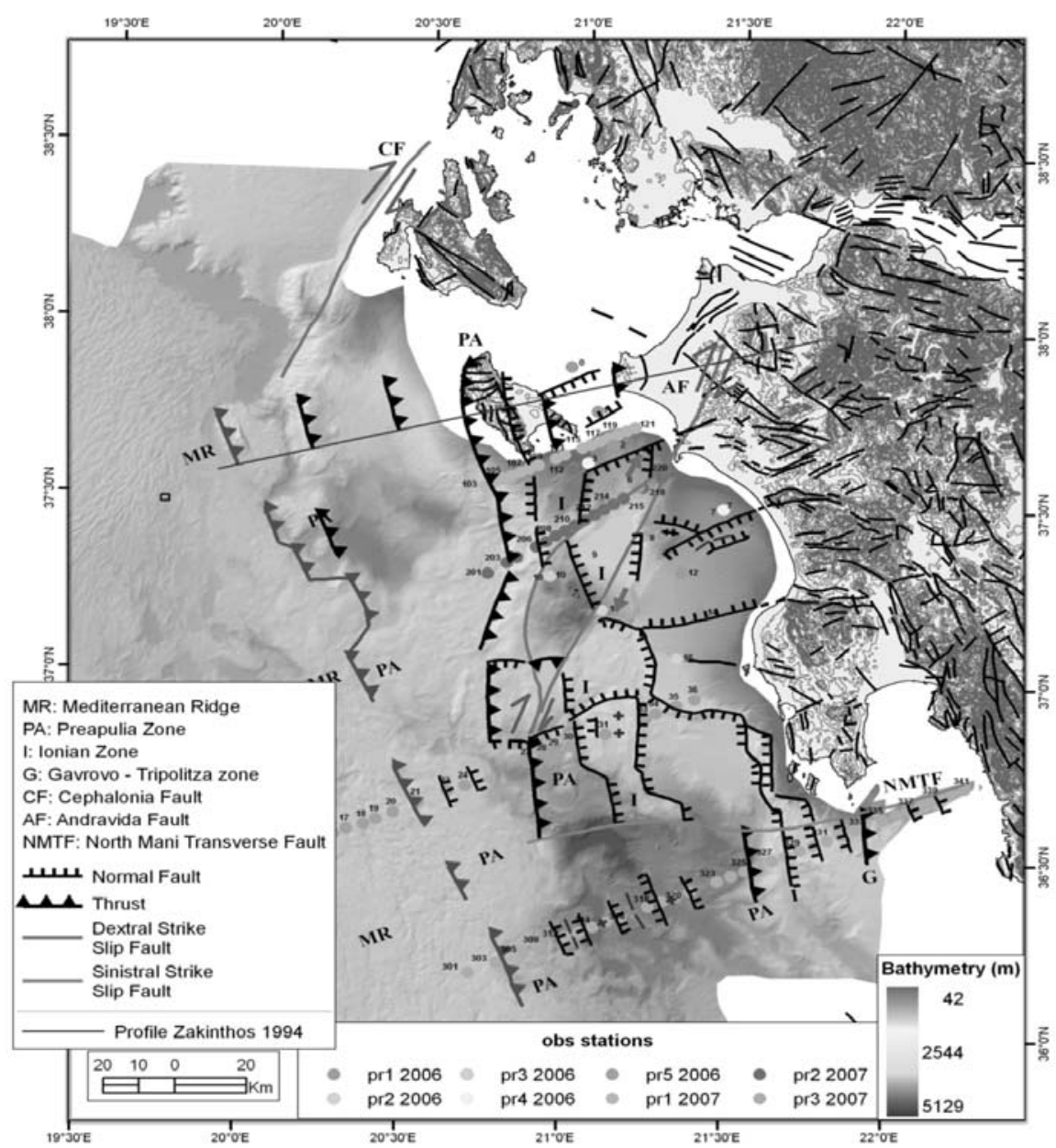

Fig. 12: Simplified structural map of the Kiparissiakos gulf showing the limit of the Mediterranean Ridge, the Hellenic napes edge, and the main tectonic elements.

two main thrusts that have been described in the velocity model of Figure 10. The other thrusted zone at the western part of the section is associated with the uplift of the Preapulia limestones and their westwards thrusting over the oceanic crust domain of the deep Ionian Sea. This is linked with a second thrusting belt close to this compressional front positioned below OBS 312 to OBS 316. It shows that the compression at this front is very intense and is spread over a significant part of the backstop.

\section{Conclusions-Results}

The active seismic experiment based on the exploitation of OBS technology was performed for the development of high quality crustal velocity models. This was also complemented by a series of multi channel seismic (MCS) lines for the delineation of the shallow sediments and their structure. Five OBS lines were established covering the complete offshore region of western Peloponnese. Our aim in locating the lines was to study the crustal structure of the block between Zakynthos island and the Gulf of Messinia. Particularly we wanted to resolve the westwards continuation of the 
Hellenic Alpine units in the offshore region, map the main tectonic elements offshore and link them to the onshore structures.

The NW-SE oriented profile 1_2006 mapped a series of faults of nearly E-W orientation. The crustal thickness in the broader Kiparissiakos area is about $22 \mathrm{~km}$ thick and the crust is continental. The sediments range between 8 and $10 \mathrm{~km}$ and in their lower part are composed of two high velocity metamorphic limestones $(\mathrm{Vp}=5.5-6.1 \mathrm{~km} / \mathrm{s})$. Triassic evaporites separate the two limestone series, producing salt dome intrusions in several locations, but have not been modelled along this line. The upper sedimentary sequences have Vp velocities between 1.8 and $3.8 \mathrm{~km} / \mathrm{s}$. Their thickness varies between 2 and $4 \mathrm{~km}$. The faults mapped along the profile have defined the N-S extension of the Kiparissiakos basin. The master faults at the northern and southern flanks of the Basin are also seismically active and truncate the entire crust. A number of faults were mapped within the Basin that correlate with the onshore fault systems, separating the internal structure of the Basin in a series of sub basins. From south to north, we have the Kiparissia basin, separated from the Olympia basin by the offshore extension of the Minthi mountains. The southern flank of this basin is seismically very active, and associated with sub crustal seismicity that extends to $90 \mathrm{~km}$ depth. The northern flank of this basin is linked with crustal seismicity. Fault plane solutions of locally recorded seismicity associated with this area have revealed mainly strike slip faulting of dextral orientation (Papoulia et al., 2009). We consider this fault system to be the offshore extension of the Andravida fault. Further to the north, offshore Katakolo, another sub basin of intense down throw has developed.

Profiles 1_2007 and 2-2007 of ENE-WSW orientation are parallel to the southern coast of Zakynthos and have mapped the northern part of the Kiparissiakos basin and its crust and sediment structure between the coast of western Peloponnese and the Zakynthos and Strophades uplifts. Crustal thickness along both lines varies between 19 and $22 \mathrm{~km}$, always thickening to the east. The thinnest part of the crust coincides with the highest uplift of the Preapulia metamorphic limestone that is thrusted westwards. The continental crust is depressed and the water depth increases systematically up to $3000 \mathrm{~m}$ at the western edge of both profiles. To the east of the Preapulia thrust we mapped an upper and a lower limestone series, separated by Triassic evaporites. The lower limestone belongs to Preapulia, and extends also west of the Preapulia thrust. The upper limestone is part of the external Hellenic napes and does not exist west of the Preapulia thrust. The Thrust itself is the limit of the westwards extension of the Hellenides towards the deep Ionian Sea.

The two southern crustal profiles, P5_2006 and P3_2007, have mapped the extension of the continental crust to the west, the western limit of the backstop and its interaction with the Mediterranean Ridge. The crust mapped in the deep Ionian Sea, west of the backstop limit, is oceanic, and has a thickness of approximately $11 \mathrm{~km}$, in a water depth of $3000 \mathrm{~m}$. Sediment thickness varies between 3.2 to $4.5 \mathrm{~km}$, increasing to the east, to the Mediterranean Ridge. The igneous part of the crust with a $\mathrm{Vp}$ velocity ranging from 6.45 to $6.8 \mathrm{~km} / \mathrm{s}$ is about $6.5 \mathrm{~km}$ thick and it is part of the Tethys ocean that is now subducting below the Hellenic Arc. East of the collision front, between the continental domain of the backstop and the oceanic one of the deep Ionian Sea, the crust is thickening eastwards. Crustal thickness at the backstop area is about 17 to $18 \mathrm{~km}$. The sediments vary between 4.5 and $8.0 \mathrm{~km}$, depending on the amount of deformation that has affected them. The basic difference between the two lines is the extent of the backstop, between the collision front and the eastward limit of the Hellenic napes. Along the northern profile, the back stop is $40 \mathrm{~km}$ wide, while at the southern line it extends for over $80 \mathrm{~km}$. East of the backstop, which is defined at its eastern limit by the Preapulia limestone thrust, the crust thickens, sediment thickness also increases, and two high velocity limestones are mapped, separated by the Triassic evaporites. The lower limestone is the 
Preapulia unit, while the upper one is part of the Hellenic napes. Continental crust in this area is approximately $22 \mathrm{~km}$ thick and the sediments are strongly deformed.

We have mapped the limit between the Mediterranean Ridge and the backstop, at about 100 to $120 \mathrm{~km}$ west of the coast of Peloponnese. We have also identified the Preapulia thrust that terminates the westward extension of the Alpine Hellenic napes. It is interesting that this front is systematically shifted westwards between Zakynthos island and offshore west Messinia, where the backstop has its minimum width of only $40 \mathrm{~km}$. South of the 5_2006 profile the Preapulia thrust is significantly shifted towards Peloponnese by more than $50 \mathrm{~km}$ (Fig. 12). This is linked to the left lateral North Mani Transverse Fault (Lallemant, 1984), which is presently inactive.

Correlating the onshore geology and Alpine units with the offshore mapped tectonics, we have placed the limits of the Ionian to the Preapulia zones in the Kiparissiakos area, and the Preapulia, Ionian and Gavrovo zones south of Messinia. Nowhere beyond the Preapulia thrust to the west have we identified the existence of the Hellenic Alpine napes in the backstop area. This observation does not agree with Aubouin et al. (1976) and Le Pichon et al. (2002) who place the limit of western Hellenides deep into the Ionian Sea, extending to the Mediterranean Ridge.

The Kiparissiakos basin is strongly affected by the dextral strike slip fault of Andravida, which is displacing the geological and tectonic elements westwards. This is also responsible for the development of transtensional basins and transpressional uplifts, like the rhombic basin northeast of the Strophades island and the Strophades uplifted block. The tectonic deformation of the Strophades island is also described by Stiros (2005) and is in agreement with the general deformation pattern derived by the present observations.

\section{Acknowledgments}

Ch. Fasulaka and Th. Patrinos from GEOPRO Hamburg are thanked for seismic modeling. Dr. V. Pilipenko, Academy of Sciences Ukraine is acknowledged for the preparation of the depth migrated sections. The Captain and crew of the R/V AEGAEO HCMR and R/V EXPLORA OGS are acknowledged for their valuable help during the field operations. Dr. D. Ilinski - GEOPRO, MSc A. Tsambas and Mr. P. Pagonis - HCMR participated in field operations and data acquisition.

This study is a contribution to the FP6 EC Project SEAHELLARC.

\section{References}

Aubouin, J, and Decourt, J., 1962. Zone Preapullien zone Ionienne et zone du Gavrovo en Peloponnese occidentale. Bulletin de Société Géologique de la France, 4, 785-794.

Aubouin, J, Bonneau, M., Davidson, J., Leboulenger, P., Matesco, S., Zambetakis, A., 1976. Esquisse structurale de l'arc Egeen externe : des Dinarides aux Taurides, Bull Soc. Geol. France 18, 327-336.

Clément, C., Hirn, A., Charvis, P., Sachpazi, M. and Marnelis, F.: 2000, Seismic structure and the active Hellenic subduction in the Ionian Islands, Tectonophysics 329, Issues 1-4, 141-156.

IGME, 1989. Seismotectonic Map of Greece with seismological data, 1:500.000 scale, Athens.

Kamberis, E., Marnelis, F., Louckogiannajis, M., Maltezou, F., Hirn, A., and the STREAMERS Group, 1996. Structure and deformation of the External Hellenides based on seismic data from offshore western Greece. EAGE Special Publications, 5, 207-214.

Kokinou, E., Kamberis, E., Vafidis, A., Monopolis, D., Ananiadis, G., and Zelilidis, A., 2005. Deep seismic reflection data from offshore western Greece: a new crustal model for the Ionian sea, Journal of 
Petroleum Geology, Vol. 28 (2), 185-202.

Lallemant, S., 1984. La Transversale Nord-Mani; Etude Geologique et Aeromagnetique d'une Structure Transverse a l'Arc Egeen Extrerne. Dr. troisieme cycle, University Pierre et Maire Curie, 164 pp.

Le Pichon, X., Lallemant, S.J., Chamot-Rouke, N., Lemeur, D., Pascal, G., 2002. The Mediterranean Ridge backstop and the Hellenic napes, Marine Geology 186, 111-125.

Lyberis, N. and Bizon, G. : 1981, Signification structurale des iles Strophades dans la marge Hellénique, Marine Geology 39, 57-69.

Makris, J. and Papoulia, J., 2009. Tectonic evolution of Zakynthos island from deep seismic soundings: thrusting and its association with the Triassic evaporites, Intl. Symposium on Evaporites, Zakynthos, pp 47-54.

Mariolakos, I., Sabot, V., Fountoulis, I., Markopoulou-Diakantoni, A., Mirkou, R., 1998. Filiatra. Neotectonic Map of Greece 1:100,000. Earthquake Planning \& Protection Org., Athens.

Makris, J., 1977. Geophysical investigations of the Hellenides, Hamburg Geophysical Monographs, Vol. 34.

Makropoulos, C., and Burton, P.W., 1981. A catalogue of the seismicity in Greece and adjacent areas, Geophys. J. R. astr. Soc., 65, 741-762.

Monopolis, D. and Bruneton, A.: 1982, Ionian Sea (Western Greece): its structural outline deduced from drilling and geophysical data, Tectonophysics 83, 227-242.

Nikolaou, K., 1986. Contribution to the study of the Neogene and the geology and boundaries of Ionian and pre-Apulian isopic zonesin relation to petroleum geology observations mainly in the Islands Strophades, Zante, Cephalonia PhD Thesis Univ. of Athens, Athens (in Greek).

Papanikolaou, D., Fountoulis, J., Metaxas, Ch., 2007. Active faults, deformation rates and Quaternary paleogeography at Kyparissiakos Gulf (SW Greece) deduced from onshore and offshore data.

Papazachos, V., and Papazachou, C., 1997. The Earthquakes of Greece, Editions Ziti.

Papoulia, J., Makris, J., Tsambas, A., and Fasulaka, Ch., 2010. Seismic deformation in the southwestern Hellenic arc: Preliminary results from active and passive seismic observations, Bull. Geol. Soc. Gr. (in press).

Pilipenko, V. and Makris, J., 1997, Application of migration to the interpretation of WARP data. Expanded Abstracts of the 69th SEG Meeting, Dallas.

SEAHELLARC EC FP6 project, Technical Reports, www.seahellarc.gr.

Stiros, S., 2005. Geodetic evidence for mobilization of evaporates during the 1997 Strophades (W Hellenic Arc) $6.5 \mathrm{M}_{\mathrm{w}}$ earthquake, J. Geophys. Eng. 2, 111-117.

Underhill, J. R., 1989. Late Cenozoic deformation of the Hellenides foreland, western Greece, Geological Society of America Bulletin 101(5), 613-634. 